\title{
PROFESSIONAL DEVELOPMENT OF TEACHERS IN THE CONTEXT OF DIGITALIZATION OF EDUCATION: FROM CONCEPTUAL IDEAS TO PRACTICE
}

\author{
Антонов Н.В., Иванова О.А. \\ ПРОФЕССИОНАЛЬНОЕ РАЗВИТИЕ ПЕДАГОГОВ В УСЛОВИЯХ ЦИФРОВИЗАЦИИ \\ ОБРАЗОВАНИЯ: ОТ КОНЦЕПТУАЛЬНЫХ ИДЕЙ К ПРАКТИКЕ
}

\begin{abstract}
The article presents the results of a study of the practice of teachers' professional development in the context of digitalization of education carried out in order to identify the features of teachers' professional development and the main conceptual ideas implemented in different countries. The article examines the practice of teachers' professional development in other countries as well as in a number of Russian regions. The analysis of pedagogical literature and scientific articles was carried out using the method of apperception and the descriptive method. The use of apperception method allowed us to expand information about the existing professional development practices implemented in different countries and regions. The use of descriptive method in working with scientific literature made it possible to select articles based on keywords, "descriptors". In this study, the following phrases were used as descriptors: "professional development of
\end{abstract} teachers", "concepts of professional development of teachers", "advanced training of teachers", "practice of professional development of teachers". As a result, practices of teachers' professional development have been identified that have both similar conceptual ideas and some national or regional features. Two of the conceptual ideas reflected in almost all countries are particularly noteworthy: that of continuity and that of personalization of teachers' professional development in the context of education digitalization. Implementation of these ideas makes it possible to ensure continuous professional development of a teacher taking into account his or her professional experience, expertise, professional competencies and interests, as well as the interests and demands of the educational organization in which he or she works. The implementation of these ideas is carried out through integration of formal and non-formal education, as well as through self-
Аннотация. В статье представлены результаты исследования практики профессионального развития педагогических работников в условиях цифровизации образования с целью выявления особенностей профессионального развития педагогов и основных концептуальных идей, которые реализуются в различных странах. В данной статье рассмотрена практика профессионального развития педагогов зарубежных стран, а также ряда российских регионов. Анализ научно-педагогической литературы, научных статей осуществлялся с использованием методов апперципирования и дескриптивного метода. Использование метода апперципирования позволило расширить сведения о существующих практиках профессионального развития, реализующихся в разных странах и регионах. Использование дескриптивного метода при работе с научной литературой позволило осуществлять отбор статей на основе ключевых слов, «дескриптов». В данном исследовании в качестве дескриптов использовались следующие словосочетания: «профессиональное развитие педагогов», «концепции профессионального развития педагогов», «повышение квалификации педагогов», «практика профессионального развития педагогов». В результате выявлены практики профессионального развития педагогов, которые имеют как одинаковые концептуальные идеи, так и национальные и региональные особенности. Среди концептуальных идей, которые нашли отражение практически во всех странах, следует отметить идеи непрерывности и персонификации профессионального развития педагогов в условиях цифровизации образования. Реализация этих идей позволяет обеспечить непрерывное профессиональное развитие педагога с учетом его профессионального стажа, опыта и тех профессиональных компетенций, которыми владеет педагог, его интересами, а также интересами и запросами образовательной организации, где он работает. Реализация этих идей осуществляется через интеграцию формального, неформального 
education and self-development of teachers in the context of education digitalization.

Keywords: conceptual ideas, professional development, advanced training, digitalization, digital educational environment.

About the authors: Antonov Nikolay Viktorovich, ORCID: 0000-0003-3118-6162, Ph.D., Department of Education and Science of the City of Moscow, Moscow, Russia, Antonovnv80@mail.ru; Ivanova Olga Anatolevna, ORCID: 0000-0002-7043-4870, Dr. habil., Moscow City Pedagogical University, Moscow, Russia, ivanovaoa@mgpu.ru образования и через самообразование, саморазвитие педагогов в условиях цифровизации образования.

Ключевые слова: концептуальные идеи, профессиональное развитие, повышение квалификации, цифровизация, цифровая образовательная среда

Сведения об авторах: Антонов Николай Викторович, ORCID: 0000-0003-3118-6162, канд. пед. наук, Департамент образования и науки города Москвы, г. Москва, Россия, Antonovnv80@mail.ru; Иванова Ольга Анатольевна, ORCID: 0000-00027043-4870, д-р пед. наук, Московский городской педагогический университет, г. Москва, Россия, ivanovaoa@mgpu.ru

Antonov N.V., Ivanova O.A. Professional Development of Teachers in the Context of Digitalization of Education: from Conceptual Ideas to Practice // Bulletin of Nizhnevartovsk State University. 2021. № 4(56). C. 5-15. https://doi.org/10.36906/2311-4444/21-4/01

Antonov, N.V., \& Ivanova, O.A. (2021). Professional Development of Teachers in the Context of Digitalization of Education: from Conceptual Ideas to Practice. Bulletin of Nizhnevartovsk State University, (4(56)), 5-15. https://doi.org/10.36906/2311-4444/21-4/01

Introduction. The rapid changes taking place in all spheres of life, the development of material and digital technologies, the emergence of new digital tools and their inclusion in everyday life presupposes not only the need to explore them and to use them proactively in professional activities, but also the need for active professional development, which is instrumental to further scientific and technological progress as well as to life success of an individual. The idea of continuous professional development is becoming increasingly relevant in the context of the dynamically developing labour market, in a world where new professions are emerging, conditions are changing and professional activity is being transformed; where employers' demands are increasing while personal professional interests and preferences are changing, thus making the concept of "lifelong learning" a reality rather than a mere slogan.

Experiment. There are multiple approaches to understanding the term professional development in psychological and pedagogical studies.

In foreign research reports, publications, and conference papers, the term continuous professional development (CPD) has been increasingly used instead of the previously employed terms in-service training and on the job training [1-4].

Russian researchers have traditionally used the term on the job training as well as the more modern term teacher growth. However, at present, the term professional development of educators, professional development of teachers, or continuous professional development is becoming increasingly popular [5-7].

For example, L.M. Mitina understands professional development as active qualitative transformation by the teacher of his or her inner world, internal determination behind the teacher's activity, which results in a fundamentally new way of professional self-realization and, a 
completely new way of living [8]. N.V. Antonov and O.A. Ivanova consider professional development as a process of active transformation by a person of his or her inner world through formation and development of professionally relevant knowledge and skills, personal abilities and qualities, motivation, activities, skills of communication and self-reflection, which are instrumental to successful creative self-realization of a teacher in his or her professional activity [9].

Continuous professional development of an educator, i.e. a professional providing instruction and guidance, is nowadays becoming a problem of paramount importance.

A number of contradictions determines professional development of teachers in the context of digitalization; one of them is connected to the fact that there is no well-established concept of "digitalization of education". For example, A.Yu. Uvarov considers digitalization of education as "achieving the necessary educational results and moving towards personalization of the educational process through the use of DT" [10].

M.E. Vaindorf-Sysoeva and L.M. Subocheva define digitalization as "the process of transferring pedagogical functions and pedagogical processes previously performed by people and organizations to the digital environment by means of using big data to organize learning and education processes; introduction of digital technologies into the content of subjects", as well as encouraging participants in the educational process to engage in independent search and processing of information, and to use mobile technologies that expand opportunities for enhancing cognition, communication and experience sharing, thus virtually erasing the boundaries of learning [11].

The pedagogical dictionary defines digitalization as transferring the educational process into a single digital educational environment and using digital hardware and software, information and digital technologies for its implementation in order to improve various aspects of the educational process and to enhance its results through a qualitative change in the relation of the participants in the educational process to each other and to learning / teaching [12].

A number of experts in the field of digitalization of education suggest considering the term digitalization in a narrow sense and a broad sense, understanding digitalization in the narrow sense as transition from the analogue form of information transmission to the digital one, "transformation of information into digital form, which in most cases leads to lower costs, emergence of new opportunities, etc.", and digitalization in the broad sense as "a modern global trend in the development of the economy and society which is based on the transformation of information into digital form and leads to an increase in economic efficiency and an improvement in the quality of life".

Analysis of other countries' practices of teachers' professional development and of the Russian system of post-diploma professional education shows that there are a number of common points connected to the ideas of continuity and personalization of teachers' professional development. For example, Singapore has been implementing the idea of continuous professional development of teachers, and the system of advanced training is closely interrelated there with the 
system of continuous training of teaching staff, from a student's admission to university to his or her employment and further professional growth [13].

Actually, Singapore has several models and regulatory frameworks for teachers' professional development, but they are all focused on the desired results of training. This resultoriented framework has fundamental significance for determining and achieving educational results by students at all levels, and correlates with the skills and abilities necessary for any person in the $21^{\text {st }}$ century. Teacher training and advanced training are carried out in four directions:

1) understanding of students' psychology and learning processes;

2) understanding of the subject (subject content) and the educational goals;

3) understanding of teaching methodology;

4) adoption of the Singapore Curriculum Philosophy.

(The model of professional growth of a teacher in Singapore. Electronic resource (https://clck.ru/Yyris).

In China, an idea of teachers' professional development is implemented that is in many ways similar to that of Singapore; however, it is more technologized and aimed at increasing student achievement and improving the quality of education in the country.

The system of continuous pedagogical education in China comprises the following components: core cultural, psychological, and professional pedagogical. Two practices of teachers' professional development can be distinguished in China: one is intended for young professionals who need to successfully adapt to working in difficult conditions, learn to work in a team, or work with limited resources, especially in rural schools, while the other is advanced training for experienced teachers. The practice of mentoring and on the job training has become widespread. This practice gives a powerful impetus to the development of the educational organization, forms the corporate culture of the school, develops cooperation, and builds team spirit [14].

In Hong Kong, the modern model of continuous learning began to take shape in early $21^{\text {st }}$ century, while retaining certain elements of the two previous models, the "knowledge-based" one and the "multifunctional" one, due to traditional social attitudes conditioned by the culture of Confucianism, traditional respect for knowledge and educated people [3]. Conceptual changes in the Hong Kong model were due to the influence of new trends emerging in the education systems of English-speaking countries. The national conceptual ideas are based on changing the teacher's position and role: "teacher as an employee" - "teacher as a provider of quality education" "teacher as a subject of continuous learning, motivated to intensive cooperation in the process of such training". The teacher's own experience and professional practices studied for further improvement serve as the sources of continuous learning [15-17].

The results of analysis of the practice of teachers' professional development in Hong Kong can be presented in a generalized form as the following list of formats:

- Active mini-studies (the teacher's self-reflection regarding his or her own teaching activities); 
- Mentoring as the basis of the mandatory "induction into the profession" program for young teachers;

- Professional communication via social media on the Internet;

- Intensive interaction of teachers within the team - joint planning, monitoring and analysis of lessons, joint discussion of relevant literature, opinion sharing, joint work on curricula and research projects;

- Experience sharing, in-service training, demo lessons;

- Workshops and short courses.

The presented set of practices generally accepted in Hong Kong can be considered as the basis of motivational mechanisms underlying teachers' growth and development "on the job", mechanisms which are based on the cultural, historical and religious characteristics and values of the country: the need for intensive communication and the sense of belonging (five fundamental lines of building relationships in Confucianism: ruler and subjects, father and son, elder and junior, husband and wife, friends); the importance of support and approval from others, willingness to provide support and assistance (the path to spiritual perfection in Confucianism and Buddhism lies through helping other people); ancient Eastern tradition of respect for philosophers and humanitarians [18].

In Finland, an important sign of teachers' professional development is implementation of the principles of equality and fairness in obtaining quality education for teachers and children, availability of quality education regardless of status or place of residence, which provides excellent results both nationally and internationally. An educational portal has been created for teachers that solves the tasks of expanding teachers' opportunities through the use of scientifically based methods of Finnish pedagogy.

It should be noted that the Finnish practice of teachers' professional development is characterized by strict selection process for entry to teacher training, compliance of professional development programs with modern trends, integration and interdisciplinary connections, practice-oriented and personalized approaches, as well as peer-to-peer training, encouragement of self-assessment of training, inclusion of project work in professional development practices, training groups of teachers in various centres (school, resource, interschool, competence development, educational, LUMA centres), programs of induction into the profession, development of the institute of mentoring and tutoring, formation of multicultural competencies as well as subject skills. The formats of training are selected by the teacher based on the results of self-reflection regarding his or her own professional activities as well as taking into account the opinions of professional development specialist consultants and the results of narrative practices of pedagogical communities (https://clck.ru/Yzb23).

The practice of professional development of teachers in the Republic of Latvia is of great interest, since improvement of professional competence is regarded there as every teacher's general responsibility, and a teacher can use 30 days every three years for advanced training and professional development while continuing to receive salary at the educational institution where he or she works. It should be noted that the rights of teachers to additional professional education 
in Latvia are established by the Law on Education, the number of training hours funded by the state is regulated, and the quality of professional activity of the teacher is assessed (https://clck.ru/Yzb2Z).

In Latvia, as well as in other countries described above, it is possible to single out the idea of continuity and the person-oriented character of teachers' professional development.

Analysis of the practices of professional development implemented in different regions of Russia indicates that our domestic education system has amassed extensive experience in teachers' advanced training in the context of education digitalization. Thus, the Novosibirsk Region has launched a digital resource called the Automated System for Monitoring Professional Development of Educational Workers in the Novosibirsk Region. The system makes it possible to automatize assessment of professional competencies of teachers in secondary education institutions with the purpose of consequent construction of personalized training route [18].

Similar practices have become widespread in the Kaliningrad, Tomsk, Tyumen regions and in a number of other regions of Russia. The Republic of Tatarstan has been effectively implementing a teacher professional development practice based on a personalized model of advanced training, when the teacher himself determines the most relevant areas and topics, as well as the forms of training, and the system of the Electronic Education in the Republic of Tatarstan portal automatically forms groups of participants in a training course. Non-formal teacher training is implemented in Tatarstan through a system of grants: Our Best Teacher, Teacher and Researcher, Best Teacher in the Field of ICT, Expert Teacher, Teacher and Mentor, Master Teacher, etc. (https://clck.ru/Z9wF2).

It should be noted that Tatarstan is currently implementing a joint project with the Singapore company EDUCARE to train teachers in the methods used in Singapore schools.

Digitalization requires a teacher to have new and totally different competencies necessary for organizing the process of education in the context of digital educational environment. In order to ensure continuous professional development of teachers, the city of Moscow has created a digital platform where all post-diploma professional education programs are accumulated. Teachers and heads of educational institutions have the opportunity to choose a program of advanced training or retraining based on the professional deficits and the teacher's interests and expectations, while integrating resources of both formal and non-formal training. Teachers' professional development in the context of digitalization makes it possible to

- implement an individual/personalized approach to the teaching staff by means of introducing individual educational pathways through digital footprint analysis (Big Data);

- integrate digital resources, tools, learning and e-learning platforms into educational activities;

- integrate the educational resources of various educational organizations and the sociocultural potential of the urban environment;

- accumulate non-formal teacher training resources: contests, workshops, Olympiads, conferences, webinars, seminars, creative encounters, etc.; 
- find like-minded colleagues, interact with them, discuss professional topics and achievement of results, and share experience;

- organize professional skill competitions in various areas, including with the use of digital educational environment;

- carry out professional activities and development in the field of selection of content, technologies and methods of educational activities, assessment of results, selection of digital and e-learning tools.

The practice of continuous professional development of teachers in the context of digitalization must have a conceptual basis and develop within the framework of certain approaches and principles, pedagogical norms of didactic and regulatory nature.

Continuous professional development of teachers in an open digital educational environment should be carried out taking into account systemic changes in education, major global trends and the best foreign and domestic practices, resources and opportunities of the socio-cultural potential of the city (region) for ensuring competitive advantage of all subjects of education (educational organizations, teaching staff and graduates of educational organizations).

The following ideas can be singled out as the basic conceptual ideas of teachers' professional development:

- In the context of systemic changes in education, it is impossible to ensure the competitiveness of teachers (as well as other subjects of education) without providing continuous professional development of pedagogical staff.

- Professional development should be considered as achievement of a higher level of readiness to successfully solve new and relatively more complex professional tasks resulting from a number of innovations in the field of education, as well as from changes in the way of organizing teaching activities in compliance with the requirements of professional standards.

- In our opinion, the following principles should be regarded as the main principles of teachers' professional development: prediction, continuity, personalization, participatory management, network interaction and communication.

The principle of prediction in teachers' professional development presupposes construction of strategic scenarios for professional and personal development of a teacher depending on the predictive analysis of the educational situation and its trends, and based on diagnostics (selfdiagnostics) of professional deficits.

The principle of continuity implies that in the context of constant changes in education, it is necessary to alter the current pedagogical activity, to develop new competencies necessary for its successful implementation, and, consequently, to correct the pathway of professional development so as to achieve continuity of self-education - to ensure learning with an orientation towards the prospects of personal and professional growth.

The principle of personalization presupposes identification and cultivation of the individual component of the personality through self-reflection - comprehension of one's own experience and addition of "individually missing" professional competencies in the context of the newly emerging professional needs and new literacies significant in the modern era. 
The principle of participation is aimed at independence and active involvement of the teacher in selection and elaboration of a professional development strategy, in realization of his or her professional potential, in development of the qualities and professional competencies that are relevant both for the teacher and for the educational organization.

The principle of network interaction and communication predetermines the range of mobile forms of integration of various resources (digital, methodological, information, personnel and other) of educational organizations for the implementation of organizational and content mechanisms making up models of teachers' professional development:

- Teachers' professional development should be carried out within the framework of a certain model of professional development and institutional structure that will function as the aggregator of ideas, values, content, organization and control.

- Continuous nature of teachers' professional development is possible in the context of systemic changes in education only on the basis of integration of formal, non-formal, and informal education, and given a high level of motivation for self-development.

- Continuous professional development of teachers should be based on the use of network interaction technologies, network partnerships with educational organizations demonstrating best practices; various forms of support for professional development of pedagogical staff, including psychological and pedagogical, methodological, and tutoring support; mentoring, in-service training, "horizontal training" with the participation of professional pedagogical communities; intraorganizational forms of development of pedagogical staff along the lines of "learning organizations"; various forms of self-education of pedagogical staff.

- Forms, methods, and technologies of professional development should be actively changed in accordance with the changes taking place in the open digital educational environment of the capital; it is necessary to create a single digital educational space to ensure continuous professional development of pedagogical staff.

- The continuity of professional development of pedagogical staff should be based on interaction with professional communities (pedagogical staff associations; teachers' methodological associations of various levels; project groups and clubs, for example, clubs of young teachers, etc.).

In our opinion, professional development of pedagogical staff should be based on the philosophy of strategic controlling, which is an important resource of an educational organization. The use of this method makes it possible to respond in a timely manner to systemic changes in the external environment, to current trends in education, and gives the opportunity to achieve competitive advantage, focusing on the society's need for professional staff.

The philosophy of strategic controlling is based on a strategic approach that makes it possible to identify trends and deficits, to analyse strategic gaps and risks connected with the development of additional professional education in integration with the development trends of the constantly changing labour market, and to preserve the best national educational traditions.

Within the framework of the strategic approach, the following methods of pedagogical praxeology are implemented: the method of praxeological description, which describes the 
patterns and conditions for shaping the correct pedagogical actions in the process of exploring and introducing changes and innovations; the method of fixing experience of effective work; the method of praxeological appraisal, aimed at assessing the structure of pedagogical activity from the standpoint of its productivity and the changes that occur in society, and based on technologies of self-reflection on professional and pedagogical behaviour and all types of experience, and of evaluating the teacher's actions and their results; the methods of praxeological modelling and design, the function of which is developing, testing, establishing norms of professional pedagogical activity, and searching for ways to increase its effectiveness; identification of current trends in teachers' professional development and ways of implementation takes place on a continuous basis; the method of analysing strategic gaps.

Conclusions. Practical implementation of the basic conceptual ideas is carried out in the following directions:

- Personalization of teachers' professional development, which presupposes designing individual educational programs / pathways of development through identification and cultivation of the individual component of the personality by means of self-reflection (comprehending one's own experience and supplementing the "individually missing" professional competencies in the context of emerging professional needs and new literacies important at the present time) and through implementation of scenarios of non-formal, formal, integrated and personalized teachers' professional development.

- Continuity of teachers' professional development presupposes creating the conditions and the range of opportunities necessary for teachers to improve or form new competencies throughout their professional activity through development of infrastructure, including the creation of an open digital educational environment for professional and personal growth and self-realization.

- Integration of teachers' professional development implies aggregation of various resources (digital, methodological, information, personnel and other) of educational organizations and interaction with professional communities for the purposes of implementation of organizational and content mechanisms of the model of managing teachers' professional development.

- Strategic controlling presupposes professional development of the teaching staff of educational organizations with regard to systemic changes in the external environment, including the main areas of socio-economic development of the region and the current trends in education, to ensure increased competitiveness of education.

- Digitalization presupposes not only introduction of digital resources and technologies through creation of an open digital educational environment, but also continuous professional development of teaching staff, improvement of the quality of education and the efficiency of its functioning.

- Network interaction presupposes improvement of network cooperation of educational organizations of various levels, as well as scientific organizations, through the implementation of horizontal, vertical and mixed models. 


\section{REFERENCES}

1. Guskey, T.R. (2002). Professional development and teacher change. Teachers and teaching, 8(3), 381-391. https://doi.org/10.1080/135406002100000512

2. Speck, M., \& Knipe, C. (Eds.). (2005). Why Can't We Get It Right?: Designing High-Quality Professional Development for Standards-Based Schools. Corwin Press.

3. Lam, B.H. (2015). Teacher professional development in Hong Kong compared to anglosphere: the role of Confucian philosophy. Psychology, Society and Education, 7(3), 295-310. https://doi.org/10.25115/psye.v7i3.521

4. Gracheva, L.Yu. Bagramyan, E.R., Tsygankova, M.N., Dugarova, T.T., \& Sheveleva, N.N. (2020). Teacher Professional Development Models and Practices in Foreign Educational Systems. The Education and science journal, 22(6), 176-200. (In Russ.). (In Russ.). https://doi.org/10.17853/1994-56392020-6-176-200

5. Gevorkyan, E.N., Ioffe, A.N., \& Shalashova, M.M. (2018). Teacher Training Approaches and Emphasis of Effectiveness. Russian Education and Society, 6, 70-76. (In Russ.).

6. Sheveleva, N.N., \& Chernobay, E.V. (2018). The Development of the Teacher is Potential. Russian Education and Society, 10, 95-103. (In Russ.).

7. Antonov, N.V., Ivanova, O.A., \& Bocharova, N.V. (2018). Osobennosti postroeniya individual'noi traektorii professional'nogo razvitiya pedagogov. Obrazovanie. Nauka. Nauchnye kadry, (1), 205-209. (In Russ.). Russ.)

8. Mitina, L.M. (2018). Psikhologiya truda i professional'nogo razvitiya uchitelya. Moscow. (In

9. Ivanova, O.A., Antonov, N.V. (2019). Social and pedagogical planning of teachers' professional development in educational organization. Bulletin of Nizhnevartovsk State University, (1), 51-57. (In Russ.).

10. Uvarov, A.Yu., Geibl, E., \& Dvoretskaya, I.V. (2019). Trudnosti i perspektivy tsifrovoi transformatsii obrazovaniya. Moscow. (In Russ.).

11. Vaindorf-Sysoeva, M. E., \& Subocheva, M. L. (2020). Tsifrovoe obuchenie v kontekste sovremennogo obrazovaniya: praktika primeneniya. Moscow. (In Russ.).

12. Dautova, O.B., Vershinina, N.A., Ermolaeva, M.G., Ignat'eva, E.Yu., Krylova, O.N., Surtaeva, N.N., Shilova, O.N., \& Khristoforov, S.V. (2020). Pedagogicheskii slovar': Noveishii etap razvitiya terminologii. St. Petersburg. (In Russ.).

13. Makhotin, D.A., Sheveleva, N.N., Lesin, S.M., \& Suvirova, A.Yu. (2019). Continuity of teacher professional development in foreign countrie. Innovatsionnye proekty i programmy v obrazovanii, $(5(65))$, 61-69. (In Russ.).

14. Lyan'tsen', V. (2012). Sistema pedagogicheskogo obrazovaniya v Rossii i KNR na sovremennom etape: strukturno-soderzhatel'nyi aspekt. Al'manakh sovremennoi nauki i obrazovaniya, (9), 36-38. (In Russ.).

15. Hargreaves, E., Berry, R., Lai, Y.C., Leung, P., Scott, D., \& Stobart, G. (2013). Teachers' experiences of autonomy in continuing professional development: Teacher learning communities in London and Hong Kong. Teacher development, 17(1), 19-34. https://doi.org/10.1080/13664530.2012.748686

16. Bautista, A., Wong, J., \& Gopinathan, S. (2015). Teacher professional development in Singapore: Depicting the landscape. Psychology, Society and Education, 7(3), 311-326. https://doi.org/10.25115/psye.v7i3.523

17. Korhonen, T., Lavonen, J., Kukkonen, M., Sormunen, K., \& Juuti, K. (2014). The Innovative School as an Environment for the Design of Educational Innovations. In Finnish Innovations and Technologies in Schools. Leiden, the Netherlands: Brill. Retrieved Nov 23, 2021, https://doi.org/10.1007/978-94-6209-749-0_9

18. Sheveleva, N.N. (2017). Modern technologies and forms of professional development of the teacher. Pedagogicheskoe obrazovanie i nauka, (4), 79-81. (In Russ.).

19. Smirnova, S. V. (2017). Novye podkhody k organizatsii adresnogo professional'nogo razvitiya rabotnikov obrazovaniya Novosibirskoi oblasti. In Tendentsii razvitiya obrazovaniya: kto $i$ chemu uchit uchitelei (pp. 135-145). (In Russ.).

\section{ЛИТЕРАТУРА}

1. Guskey T. R. Professional development and teacher change // Teachers and teaching. 2002. Vol. 8. № 3. P. 381-391. https://doi.org/10.1080/135406002100000512 
2. Speck M., Knipe C. (ed.). Why Can't We Get It Right?: Designing High-Quality Professional Development for Standards-Based Schools. Corwin Press, 2005.

3. Lam B. H. Teacher professional development in Hong Kong: compared on anglosphere: the role of Confucian philosophy. 2015. https://doi.org/10.25115/psye.v7i3.521

4. Грачева Л.Ю., Баграмян Э.Р., Цыганкова М.Н., Дугарова Т.Ц., Шевелева Н.Н. Модели и практики профессионального развития учителей в зарубежных системах образования // Образование и наука. 2020. Т. 22. № 6. С. 176-200. https://doi.org/10.17853/1994-5639-2020-6-176-200

5. Геворкян Е.Н., Иоффе А.Н., Шалашова М. М. Повышение квалификации педагогов: подходы и акценты результативности // Педагогика. 2018. № 6. С. 70-76.

6. Шевелева Н.Н., Чернобай Е.В. Развитие учительского потенциала // Педагогика. 2018. № 10. C. 95-103.

7. Антонов Н. В., Иванова О. А., Бочарова Н. В. Особенности построения индивидуальной траектории профессионального развития педагогов // Образование. Наука. Научные кадры. 2018. № 1. С. 205-209.

8. Митина Л.М. Психология труда и профессионального развития учителя. М.: Академия, 2004. $318 \mathrm{c}$.

9. Иванова О.А., Антонов Н.В. Профессиональноеразвитиепедагогов в условиях образовательной организации // Вестник Нижневартовского государственного университета. 2019. № 1. С. 51-57.

10. Уваров А.Ю., Гейбл Э., Дворецкая И.В. Трудности и перспективы цифровой трансформации образования. М.: Издательский дом Высшей шк. экономики, 2019. 343 с.

11. Вайндорф-Сысоева М.Е., Субочева М.Л. Цифровое обучение в контексте современного образования: практика применения. М.: Диона, 2020. 244 с.

12. Даутова О.Б., Вершинина Н. А., Ермолаева М.Г., Игнатьева Е.Ю., Крылова О.Н., Суртаева Н.Н., Шилова О.Н., Христофоров С.В. Педагогический словарь: Новейший этап развития терминологии. СПб: КАРО, 2020. 328 с.

13. Махотин Д.А., Шевелёва Н.Н., Лесин С.М., Сувирова А.Ю. Непрерывность профессионального развития педагогов в зарубежных странах // Инновационные проекты и программы в образовании. 2019. № 5(65). С. 61-69.

14. Ляньцэнь В. Система педагогического образования в России и КНР на современном этапе: структурно-содержательный аспект // Альманах современной науки и образования. 2012. № 9. С. 3638.

15. Hargreaves E., Berry R., Lai Y.C., Leung P., Scott D., Stobart G. Teachers' experiences of autonomy in continuing professional development: Teacher learning communities in London and Hong Kong //Teacher development. 2013. Vol. $17.2 №$ 1. P. 19-34. https://doi.org/10.1080/13664530.2012.748686

16. Bautista, A., Wong, J., \& Gopinathan, S. (2015). Desarrollo profesional docente en Singapur: Describiendo el Panorama // Psychology, Society and Education, Vol. 7. № 3. P. 423-441. https://doi.org/10.25115/psye.v7i3.523

17. Korhonen T., Lavonen J., Kukkonen M., Sormunen K., Juuti K. The Innovative School as an Environment for the Design of Educational Innovations // Finnish Innovations and Technologies in Schools. SensePublishers, Rotterdam. 2014. https://doi.org/10.1007/978-94-6209-749-0_9

18. Шевелева Н. Н. Современные технологии и формы профессионального развития учителя // Педагогическое образование и наука. 2017. № 4. С. 79-81.

19. Смирнова С. В. Новые подходы к организации адресного профессионального развития работников образования Новосибирской области // Тенденции развития образования: кто и чему учит учителей. 2017. С. 135-145. 